\title{
Formation of mathematical concepts by the intellectually disabled by means of soroban
}

\author{
Formación de conceptos matemáticos por personas con \\ deficiencia intelectual por medio del soroban
}

\author{
Lucia Virginia Mamcasz-Viginheski* \\ ORCID iD 0000-0002-6474-0927 \\ Sani de Carvalho Rutz da Silva** \\ ORCID iD 0000-0002-1548-5739 \\ Elsa Midori Shimazaki** \\ ORCID iD 0000-0002-2225-5667 \\ Marcio Pascoal Cassandre ${ }^{* * * *}$ \\ ORCID iD 0000-0001-9415-4315
}

\begin{abstract}
The aim is to assess contribution provided by soroban - or Japanese abacus - not only for the students' learning of number and operations content, but also in the development of their higher psychological functions. As an applied nature, it was developed under a pedagogical intervention for data collection and analysis. The eight participants were adult students, aged 19 to 47 years old, who attended a special education school in a city in the countryside of the state of Paraná - Brazil. The data was analyzed through assessment of the conversation. The students with intellectual disabilities participating in the study had limited knowledge regarding the use of numbers and operations in school situations and in different contexts of everyday life, so these concepts were taught to them. After the pedagogical intervention, they showed advances in this knowledge, appropriating both the concept of numbers and the use of soroban as a tool for performing mathematical calculations. As it is a human right to appropriate the knowledge produced historically and culturally by mankind, which in turn leads to development,
\end{abstract}

* Doutora em Ensino de Ciência e Tecnologia pela Universidade Tecnológica Federal do Paraná (UTFPR). Docente do Programa de Pós Graduação em Promoção da Saúde do Centro Universitário UniGuairacá, Guarapuava, Paraná, Brasil e do Programa de Pós Graduação em Ensino de Ciências e Educação Matemática da Universidade Estadual de Ponta Grossa (UEPG). Docente da Associação de Pais e Amigos dos Deficientes Visuais (APADEVI), Guarapuava, Paraná, Brasil. Endereço para correspondência: Rua Expedicionário João Maria Batista, 1251, Alto da XV, Guarapuava, Paraná, Brasil, CEP: 85070-696. E-mail: lucia.virginia @uniguairaca.edu.br.

** Doutora em Ciências dos Materiais pela Universidade Federal do Rio Grande do Sul (UFRGS). Docente do Programa de Pós Graduação em Ensino de Ciência e Tecnologia da Universidade Tecnológica Federal do Paraná (UTFPR), Ponta Grossa, Paraná, Brasil. Endereço para correspondência: Av. Monteiro Lobato, Km 04, Ponta Grossa, Paraná, Brasil, CEP: 84016-210. E-mail: sani@utfpr.edu.br.

*** Doutora em Educação, Universidade de São Paulo (USP). Docente dos Programas de Pós Graduação em Educação da Universidade do Oeste Paulista (Unoeste) e da Universidade Estadual de Maringá (UEM), Maringá, Paraná, Brasil. Endereço para correspondência: Av. Colombo, 5790, Zona Sete. Departamento de Teoria e Prática da Educação, Maringá, Paraná, Brasil, CEP: 87020-900. E-mail: emshimazaki@uem.br.

***** Doutor em Administração, Universidade Positivo. Líder da Divisão Acadêmica Gestão de Pessoas e Relações de Trabalho na Associação Nacional de Pós-Graduação e Pesquisa em Administração, Universidade Estadual de Maringá (UEM), Maringá, Paraná, Brasil. Enrereço para correspondência: Av. Colombo, 5790, Zona Sete. Departamento de Administração, Maringá, Paraná, Brasil, CEP: 87020-900. E-mail: mpcassandre@uem.br. 
teaching the use of soroban to students with intellectual disabilities promoted the learning of mathematical concepts, developing superior skills such as thought, defending the thesis proposed by this study that cognitive limitations of the intellectually disabled are not barriers to learning of an array of educational concepts.

Keywords: Mathematics Teaching. Soroban. Intellectual Disability. Learning. Development.

\section{Resumen}

El presente artículo es producto de una investigación que tuvo como objetivo comprobar las contribuciones del soroban, también llamado de ábaco japonés, para el aprendizaje del contenido de Educación Matemática "números y operaciones", bien como para el desarrollo de las funciones psicológicas superiores en estudiantes con deficiencia intelectual. Los sujetos de estudio fueron ocho estudiantes adultos, de entre 19 y 47 años, que frecuentan una escuela de educación especial en un municipio del Estado del Paraná, Brasil. Se utilizó la observación participante e intervención pedagógica como herramientas para la colecta de datos, los que fueron registrados a partir de medios audio-visuales y diarios de campo. El análisis de datos reveló que los estudiantes con deficiencia intelectual presentaban conocimientos limitados en lo que se refiere al uso de números y operaciones, y no solo en situaciones escolares, sino también en distintos contextos cotidianos. Debido a ello, estos conceptos fueron enseñados teniendo como herramienta pedagógica el soroban. Después de esta intervención, los y las estudiantes presentaron avances, puesto que se apropiaron del concepto "número" y aprendieron a utilizar el soroban para la realización de operaciones matemáticas. Se considera como un derecho de todas las personas el apropiarse del conocimiento histórico-cultural producido por la humanidad; uno de estos es la utilización de números para realizar cálculos matemáticos. Nuestra investigación demuestra que la enseñanza del uso de soroban en estudiantes con deficiencia intelectual favorece el aprendizaje de los conceptos trabajados, desarrollando capacidades superiores como el pensamiento. Esto permite defender la tesis propuesta en el estudio: que las limitaciones cognitivas de personas con deficiencia intelectual no deben entenderse como barreras para el aprendizaje de "números y operaciones".

Palabras clave: Enseñanza de Matemáticas. Soroban. Deficiencia Intelectual. Aprendizage. Desarrollo.

\section{Introduction}

Access to education by disabled students is a right protected by Brazilian legislation, such as the Federal Constitution (BRASIL, 2016), Laws for Guidelines and Bases of National Education (BRASIL, 2017). Students attending school, whether participating in general or Special Education (SE), also comprise intellectually disabled learners.

Intellectual disability is understood herein as "[...] a disability characterized by significant limitations both in intellectual functioning (reasoning, learning, problem-solving) and in adaptive behavior, which covers a range of everyday social and practical skills. This disability originates before the age of 18." (SCHALOCK et al., 2010, p. 6). It is understood that a diagnosis of intellectual disability is achieved according to a combination of limitations involving cognitive, motor, social, and language-related areas.

Adults with this disability, whose age is considered advanced in relation to the rest of the students, when in search of schooling, are placed in programs such as EJA (Youth and Adults Education), one of the modalities of the Brazilian Educational System which objectively offers academic certification and placement in the workforce and consequently, in society. This type 
of education, supported by Law 9394/1994, receives students from elementary and middle education. From 15 years of age in elementary school and from 18 years of age in high school. It aims to offer formal education to those people who did not continue studying at the appropriate age. According to data from the Instituto Nacional de Estudos e Pesquisas Educacionais Anísio Teixeira - INEP in 2019, there were 1,937,583 students enrolled in EJA Elementary School in Brazil. Of these, 126,438 were students with disabilities, the main audience for Special Education. Some of the known challenges in graduating include the anticipated age for attending primary school, the school staff lack of knowledge regarding intellectual disability, the relatively low rate of technical dominion of learning and development theories, the use of methodologies that many times make appropriation of more difficult knowledge, among other things. The learning of mathematics offered by EJA, many times does not correspond to the expectations nor to the needs of these people. It is relatively commonplace for the learning mathematics to be seen as a ready, finished, a-historical science, founded on the ideas and ways of Classic Mathematics (FIORENTINI, 1995; FÁVERO; OLIVEIRA, 2004). This concept contradicts the proposals made by the National Curriculum Guidelines, which suggest teaching should happen in the relationship between real-world observations and its representations, in conjunction with mathematical principles and concepts (BRASIL, 1997).

In the same way that mathematics is offered to people without disabilities, Mathematics for students with disability has been summarized in copying and solving problems in a mechanical way, without allowing for a moment of reflection on the meaning of these actions in their lives (SHIMAZAKI; PACHECO, 2012; GOMES; POULIN; FIGUEREDO, 2010). On the other hand, studies have shown the possibility of teaching mathematics to students with intellectual disabilities overcoming traditional schooling characterized by repetitions without contextualizing within their lived realities, advancing toward learning and promoting their own development (SHIMAZAKI; PACHECO, 2012; BRITO; CAMPOS; ROMANATO, 2014; BRAUN; NUNES, 2015).

Similarly to other students, intellectually disabled students have the right to learn and develop. Furthermore, they also have the need to pursue appropriate means that allow educational objectives to be fulfilled (SHIMAZAKI; PACHECO, 2012). For those reasons, the present study proposes teaching soroban to intellectually disabled adults with the vision of assessing the contributions provided by the tool in the learning of numbers and operations, as well as to the development of students. It is understood that soroban is a mediating instrument for helping in the development of the concepts of numbers and operations for adults with intellectual disabilities. Soroban is a calculation tool developed by the Japanese, which has been 
a research subject matter in Education and Neurosciences, especially in Asian countries, such as China, Japan, Malaysia, etc. In those countries, the abacus is culturally used as the major tool for carrying out mathematical calculations (DONLAN; WU, 2017; FREEMAN, 2014; TANAKA et al., 2012; MAHPOP; SIVASUBRAMANIAN, 2010; SIANG, 2007, SHEN, 2006). The aim of the research mentioned above is to study the benefits of the tool not only for learning mathematical concepts, but also for developing abilities such as reasoning, memory, and others.

Based on the aforementioned research outcomes, it is believed that the use of soroban as a calculation tool by intellectually disabled students provides benefits to learning operationrelated contents. Additionally, it encourages the development of language, reasoning, and other higher psychological functions.

This study supports the thesis that intellectually disabled people's cognitive limitations are not barriers to learning how to use soroban as a calculation tool. Additionally, one result arising from soroban-based learning is the development of Higher Psychological Functions.

Vigotski (1997) expressed criticism towards assessing intellectually disabled people only by means of quantitative tests. The tests only provided information on a given person's real development, thus not revealing the process under development which, in turn, could not be quantitatively measured. This has led to the premise that intellectually disabled people, whether children or adults, cannot be considered as less developed people, but rather people that have developed in a different, peculiar manner.

By focusing on disabled people's abilities, rather than on their limitations, Vigotski (1997) advocates that compensation is necessary. The theorist claims every disability creates stimuli for compensation, a form of psychic energy that aids one's development in a different manner. The source, that is, the primary stimulus causing compensatory processes to arise, comprises the objective difficulties which disabled people struggle with during their development processes. In the field of intellectual disability, the theory of compensation serves as psychological basis for their education.

Another concept that Vigotski (2007) refers to is mediation, which contributed to the development of higher psychological functions. According to the theory, the interaction between humans, environment, and society becomes effective through the use of mediating instruments, whether material or psychological. The material instruments are the abacus, golden material, ruler, among others and the psychological instruments are the language, speech, writing, the Brazilian sign language, the sign, among others developed by humanity throughout its existence. Signs are constituted as psychological tools and learning happens 
when they are internalized. Thus, the theorist considered mediation to be the process that promotes learning, because these [...] are tools that assist in psychological processes and not in concrete actions" (VIGOTSKI, 2007, p. 30).

Vigotski (2007) stablishes that learning boosts development of higher psychological functions. The latter are particular to human beings and relative to mental abilities such as language, memory, attention, and reasoning, among others. This author also advocates that learning identifies and creates a Zone of Proximal Development - ZPD and make use of this as a mediator tool which consists of the interval between what a child can do with the help of others (potential development level) and what this child can do without help (real development level). Vigotski claims that by creating ZPD, learning stimulates internal development processes.

Meanwhile, interaction and compliance with other people, as well as mediation by means of tools, such as language, are of paramount importance. This is because knowledge is socially produced and once it is internalized, it becomes part of the individual development acquisitions. In turn, it results in mental development, thereby boosting the intellectually disabled towards compensation.

Therefore, whenever thinking about teaching intellectually disabled people, it is necessary to understand how they develop, in addition to taking their abilities rather than their limitations into account, and understanding the peculiarities of the disability to teaching and learning. As a result, one can come up with a pedagogical action plan aiming at teaching by means of enough and effective mediation, thereby creating and consolidating successive ZPD, while also providing them with access to and appropriation of scientific knowledge and development.

\section{Development}

This research is classified as being of an applied nature, developed by means of a qualitative approach for analysis of the data collected (MOREIRA; CALEFFE, 2008). Ensuring the relationship established between research and pedagogical practice as the goal, we proposed an intervention-based study, allowing for changes in pedagogical practices through the polysystemic process. It means not only the specific conceptual field, mathematics in this case, but also the human development concept and the social representations associated with this process (FÁVERO, 2011). 
This study was developed at an elementary school focusing on SE, which included intellectually disabled students and was located in a countryside municipality in Paraná, Brazil. This school was chosen due to concentrating a higher number of disabled students in the aforementioned municipality.

Eight students attending a Youth and Adult Education program (known in Brazil as EJA) were included in this study. Out of a total of eight, seven male and one female student, with ages ranging from 19 to 47 years old. The names Cesar, Fabricio, Hélio, José, Junior, Pedro, Tiago, e Maria are purposefully fictitious. One student had attended general education from 7 to 16 years of age. Due to successive episodes of failure in early school years, he was referred to assessment in the field of intellectual disability with the recommendation to proceed with SE based on adapted curricula. Education time for SE students ranged from 4 to 28 years. In addition to academic activities, students took part in activities related to professional training in bread making.

During preliminary research, data was collected by means of documentary research with files available at the school office. The following was included: students' personal data, intellectual disability assessment, pedagogical reports on individual teaching and learning achievements in concepts relative to numbers and operations. Additionally, a focal interview with the classroom teacher and students, as well as participatory observation during five classes were also carried out. The data allowed researchers to find that students had not developed the concepts of numbers and operations, and also provided support to establish the following investigation guideline: the intervention carried out through planning and through systematized instruments help consolidate ZDP in students with intellectual disabilities. These students will grow in their knowledge in different situations, beyond those that they experience within the school, broadening the social use of this content and promoting the development of superior psychological functions.

The action plan was developed through pedagogical intervention in which sessions aiming at teaching not only how to use the soroban, but also numbers and operations content were carried out based on guidance provided by Vigotski (2007), Galperin (2009b), Talizina (2009), Salmina (2001), and Fernandes et al. (2006). Results were assessed on the basis of the aforementioned authors' theories. Despite the research object being the content of numbers and operations, there was a connection with other contents on several occasions, including, for instance, addressing information, quantities and measures, space, and shape. This was due to the need for connection among different contents, with a vision that allowed students to relate mathematics to everyday situations they experience (BRASIL, 1997). 
A mathematics curriculum designed for EJA students attending Elementary School focusing on SE was used to introduce the soroban as a calculation tool (PARANÁ, 2014). The curriculum was comprised of operations such as sorting numbers, series, counting, quantifying, the decimal number system, addition, subtraction, and problem-solving.

Teaching sessions were developed during a 90-hour credit period distributed into three weekly meetings, each one lasting approximately 100 minutes. Table 1 presents a synthesis of concepts covered in the pedagogical intervention:

\begin{tabular}{|c|c|c|}
\hline $\begin{array}{l}\text { MATHEMATIC } \\
\text { CONTENT }\end{array}$ & LEARNING TOOLS & ACTIVITIES \\
\hline $\begin{array}{l}\text { Concept of a } \\
\text { number }\end{array}$ & Various product packaging & $\begin{array}{l}\text { Classification, forming series, counting, quantifying, and } \\
\text { grouping packaging }\end{array}$ \\
\hline $\begin{array}{l}\text { Complimentary } \\
\text { numbers }\end{array}$ & Numeric rulers & $\begin{array}{l}\text { Card games (Stealing the Pile, Battle, and War). Construction } \\
\text { of complementary numbers adding up to } 5(4+1 ; 3+2 ; 2+3 \text {; } \\
1+4) \text { and } 10(9+1 ; 8+2 ; 7+3 ; 6+4 ; 5+5 ; 4+6 ; 3+7 ; 2+8 ; 1+9) \\
\text { with numeric rules, used with a memory aid for registering } \\
\text { numbers and operations using the soroban. }\end{array}$ \\
\hline $\begin{array}{l}\text { Grouping by } 10 \mathrm{~s} \\
\text { and Numeric } \\
\text { Decimal System }\end{array}$ & $\begin{array}{l}\text { Numeric rulers and golden } \\
\text { bead material }\end{array}$ & $\begin{array}{l}\text { Nunca Dez Solto Game (Never Ten Loose) (Fernandes et al., } \\
2006 \text { ) with the golden bead material, using the numeric rulers } \\
\text { as a memory aid for complementary numbers that add up to } \\
5 \text { and } 10 \text {. }\end{array}$ \\
\hline $\begin{array}{l}\text { Adding and } \\
\text { Subtracting }\end{array}$ & Soroban & $\begin{array}{l}\text { Quantity records on the soroban and adding and subtracting } \\
\text { quantity operations. }\end{array}$ \\
\hline Problem-solving & $\begin{array}{l}\text { Grocery store calculations, } \\
\text { golden bead material and } \\
\text { soroban }\end{array}$ & $\begin{array}{l}\text { Calculating the production cost of a specific product in the } \\
\text { school bakery. }\end{array}$ \\
\hline
\end{tabular}

Table 1 - Content covered in the pedagogical intervention Source: Elaborated by the researchers.

Teaching the use of the soroban began with an explanation of its structure and the way one can go about recording numbers and performing operations of addition and subtraction of these recorded numbers. It has a rectangular in shape and a reckoning bar dividing the soroban into two parts: the upper one and the lower area. Rods are arranged vertically along the soroban, and the number of rods varies from one soroban to another. Each rod consists of four lower beads and five upper beads. The reckoning bar is marked with lines which divide the rods into classes. They have the function of a dot for operations including decimals, and the function of a line/slash for fractions. Figure 1 illustrates the tool structure: 


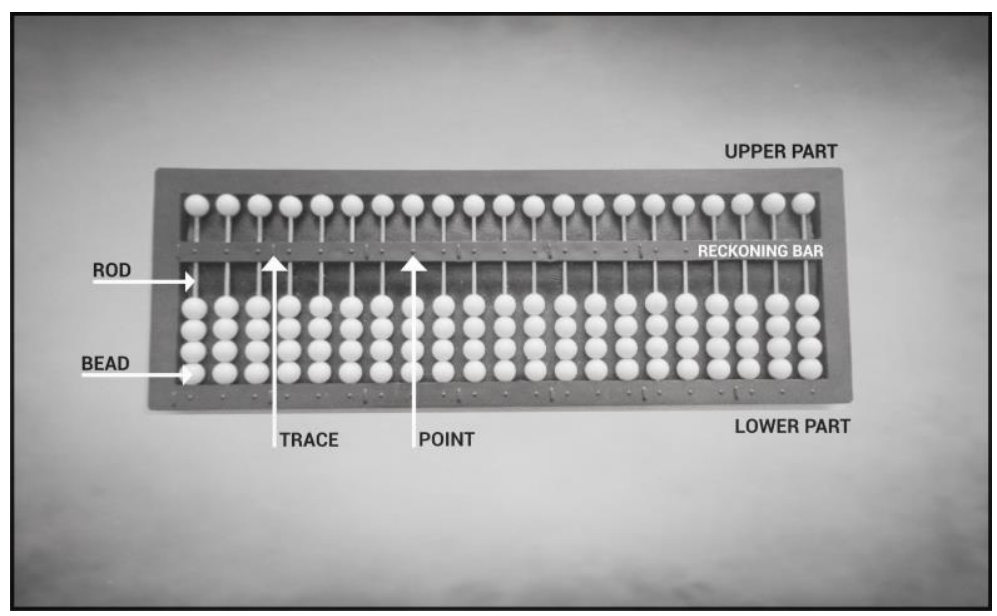

Figure 1 - Soroban structure

Source: Researchers' private collection.

Each rod represents a given order in the decimal system. From right to left, the first rod represents the units, the second rod represents the tens, the third rod represents the hundreds, and thus successively. Lower beads assume the value of one, while upper beads value five times more the corresponding order. At the rod representing units, lower beads correspond to one unit and upper beads are worth five units. At the rod representing tens, lower beads are worth ten, or a set of ten units, while upper beads are worth five sets of tens, or fifty units. At the rod representing sets of hundred, each lower bead is worth one hundred or a hundred units, while each upper bead is worth five hundred, or five hundred units.

To record a number on the soroban, it is necessary to place beads near the reckoning bar. Figure 2 illustrates representation of digits 0 to 9 and Figure 3 illustrates the record of numbers 15 and 143:

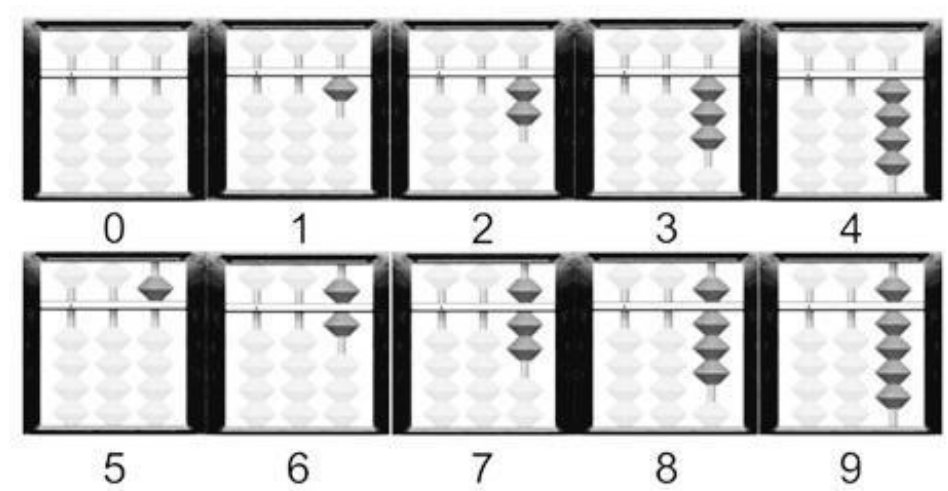

Figure 2 - Representation of digits 0 to 9

Source: Researchers' private collection 


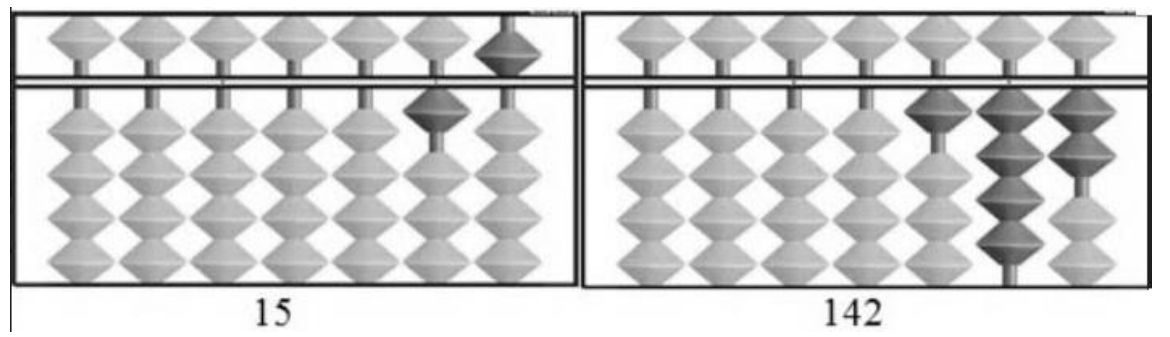

Figure 3 - Record of numbers 15 and 142

Source: Researchers' private collection.

The Mathematical concepts learning assessment was qualitative and carried out continuously and in process by examining students' individual learning development. In other words, we assessed the students' knowledge both before and after pedagogical intervention.

Results achieved at all research stages were assessed by means of conversation analysis, focusing on the context of actions and interpretations accordingly. Procedures adopted for analysis were: i) carrying out recordings of interactions that took place during interviews, teaching sessions, and within the documentation of journals; ii) transcripts of films; iii) readings of transcripts; iv) organization and data ordinance; v) identifying episodes and selecting elements for analysis through the segmentation process; vi) confirming obtained results, pointing out arguments that allow for articulated defense with the theoretic framework adopted (FLICK, 2009).

\section{Results and discussion}

\subsection{Evaluation of the mathematical concepts}

Data collected during preliminary research by means of documentary research, interviews with the classroom teacher and students, and participatory observation during classes revealed there were issues in the process of teaching and learning mathematical contents. Although most students had attended the SE program for several years, they often had not appropriated the mathematical concepts compatible with the amount of time studied. In the case of the research subjects, some had not yet appropriated the number concept necessary to learn how to use the soroban (FERNANDES et al., 2006).

Table 2 presents a synthesis of knowledge that students had prior to the intervention and what knowledge they had after the intervention. 


\begin{tabular}{|c|c|c|c|c|c|c|c|c|c|}
\hline \multirow{2}{*}{\multicolumn{2}{|c|}{ CONTENT }} & \multicolumn{8}{|c|}{ STUDENT } \\
\hline & & Cesar & Fabrício & Hélio & José & Junior & Maria & Pedro & Tiago \\
\hline \multirow[t]{2}{*}{$\begin{array}{l}\text { CONCEPT OF } \\
\text { NUMBERS }\end{array}$} & C.S. & $\begin{array}{l}\text { Was unable to } \\
\text { explain what a } \\
\text { number is. } \\
\text { Comprehensio } \\
\mathrm{n} \text { of quantities } \\
\text { up to } 20 \text {. }\end{array}$ & $\begin{array}{l}\text { Associated with money. } \\
\text { Comprehension of } \\
\text { quantities up to } 20 \text {. }\end{array}$ & $\begin{array}{l}\text { Compreh } \\
\text { ension of } \\
\text { quantitie } \\
\mathrm{s} \text { up to } 3 .\end{array}$ & $\begin{array}{l}\text { Numbers associated } \\
\text { to organization of } \\
\text { time within calendars } \\
\text { and phone numbers. } \\
\text { Comprehension of } \\
\text { quantities up to } 10 \text {. }\end{array}$ & $\begin{array}{l}\text { Was unable to } \\
\text { explain what a } \\
\text { number was. } \\
\text { Comprehension of } \\
\text { quantities up to } 50 \text {. }\end{array}$ & $\begin{array}{l}\text { Comprehens } \\
\text { ion of } \\
\text { quantities up } \\
\text { to } 3 \text {. }\end{array}$ & $\begin{array}{l}\text { Associates numbers } \\
\text { with license plates, } \\
\text { house numbers, and } \\
\text { money. } \\
\text { Comprehends } \\
\text { quantities up to } 20 \text {. }\end{array}$ & $\begin{array}{l}\text { Comprehend } \\
\text { s quantities } \\
\text { up to } 4 .\end{array}$ \\
\hline & A.S & Not observed & $\begin{array}{l}\text { Comprehension of } \\
\text { grouping by } 10 \text { s and } \\
\text { place value. }\end{array}$ & $\begin{array}{l}\text { Compreh } \\
\text { ension of } \\
\text { quantitie } \\
\text { s up to } 5 .\end{array}$ & $\begin{array}{l}\text { Comprehension of } \\
\text { grouping by } 10 \mathrm{~s} .\end{array}$ & $\begin{array}{l}\text { Comprehension of } \\
\text { quantities greater } \\
\text { than one hundred. }\end{array}$ & $\begin{array}{l}\text { Comprehens } \\
\text { ion of } \\
\text { quantities up } \\
\text { to } 5 \text {. } \\
\end{array}$ & $\begin{array}{l}\text { Comprehension of } \\
\text { grouping by } 10 \mathrm{~s} \\
\text { and place value. }\end{array}$ & $\begin{array}{l}\text { Comprehens } \\
\text { ion of } \\
\text { quantities up } \\
\text { to } 7 . \\
\end{array}$ \\
\hline \multirow[t]{2}{*}{ OPERATIONS } & C.S. & $\begin{array}{l}\text { Did not } \\
\text { perform } \\
\text { operations. }\end{array}$ & $\begin{array}{l}\text { Performed operations } \\
\text { such as simple addition } \\
\text { and subtraction. }\end{array}$ & $\begin{array}{l}\text { Did not } \\
\text { perform } \\
\text { operation } \\
\text { s. }\end{array}$ & $\begin{array}{l}\text { Did not perform } \\
\text { operations. }\end{array}$ & $\begin{array}{l}\text { Performed } \\
\text { operations such as } \\
\text { simple addition and } \\
\text { subtraction and } \\
\text { some regroupings. }\end{array}$ & $\begin{array}{l}\text { Did not } \\
\text { perform } \\
\text { operations. }\end{array}$ & $\begin{array}{l}\text { Performed } \\
\text { operations such as } \\
\text { simple addition and } \\
\text { subtraction. }\end{array}$ & $\begin{array}{l}\text { Did not } \\
\text { perform } \\
\text { operations. }\end{array}$ \\
\hline & A.S & Not observed & $\begin{array}{l}\text { Performed addition and } \\
\text { subtraction on Soroban } \\
\text { with quantities up to } 20 \text {. }\end{array}$ & $\begin{array}{l}\text { Not } \\
\text { observed }\end{array}$ & $\begin{array}{l}\text { Performed addition } \\
\text { and subtraction on } \\
\text { Soroban with } \\
\text { quantities up to } 10 .\end{array}$ & $\begin{array}{l}\text { Performed addition } \\
\text { and subtraction on } \\
\text { Soroban with } \\
\text { quantities above } \\
\text { one hundred and } \\
\text { some regroupings }\end{array}$ & $\begin{array}{l}\text { Performed } \\
\text { addition and } \\
\text { subtraction } \\
\text { on Soroban } \\
\text { with } \\
\text { quantities up } \\
\text { to } 5 \text {. }\end{array}$ & $\begin{array}{l}\text { Performed addition } \\
\text { and subtraction on } \\
\text { Soroban with } \\
\text { quantities up to } 20 .\end{array}$ & $\begin{array}{l}\text { Performed } \\
\text { addition and } \\
\text { subtraction } \\
\text { on Soroban } \\
\text { with } \\
\text { quantities up } \\
\text { to } 5 \text {. } \\
\end{array}$ \\
\hline \multirow[t]{2}{*}{$\begin{array}{l}\text { PROBLEM } \\
\text { SOLVING }\end{array}$} & C.S. & $\begin{array}{l}\text { Did not solve } \\
\text { problems }\end{array}$ & $\begin{array}{l}\text { Used addition to solve } \\
\text { every type of problem }\end{array}$ & $\begin{array}{l}\text { Did not } \\
\text { solve } \\
\text { problems }\end{array}$ & $\begin{array}{l}\text { Did not solve } \\
\text { problems. }\end{array}$ & $\begin{array}{l}\text { Demonstrated } \\
\text { having a hard time } \\
\text { identifying the } \\
\text { adequate operation } \\
\text { to use to problem } \\
\text { solve. }\end{array}$ & $\begin{array}{l}\text { Did not } \\
\text { solve } \\
\text { problems. }\end{array}$ & $\begin{array}{l}\text { Did not solve } \\
\text { problems. }\end{array}$ & $\begin{array}{l}\text { Did not } \\
\text { solve } \\
\text { problems. }\end{array}$ \\
\hline & A.S & Not observed. & $\begin{array}{l}\text { Reflected upon which } \\
\text { operation to utilize to } \\
\text { problem solve, in some } \\
\text { situations made an } \\
\text { incorrect choice. }\end{array}$ & $\begin{array}{l}\text { Not } \\
\text { observed. }\end{array}$ & Not observed. & $\begin{array}{l}\text { Reflected upon } \\
\text { which operation to } \\
\text { utilize to problem } \\
\text { solve. }\end{array}$ & $\begin{array}{l}\text { Not } \\
\text { observed. }\end{array}$ & $\begin{array}{l}\text { Reflected upon } \\
\text { which operation to } \\
\text { utilize to problem } \\
\text { solve, in some } \\
\text { situations made an } \\
\text { incorrect choice. }\end{array}$ & $\begin{array}{l}\text { Not } \\
\text { observed. }\end{array}$ \\
\hline
\end{tabular}

C.S.: Confirmed Skill observed in preliminary research;

A.S.: Acquired Skill

Table 2 - Skills acquired after the intervention

Source: Elaborated by the researchers.

Students were asked about the usefulness of numbers and everyday situations of their uses. The students' answers revealed they acknowledged numbers were part of different contexts they experienced, numbers were acknowledged in time-management, as well as in information-related situations. Quantity-related events were not included. José, for instance, recognized numbers were part of his daily life through the calendar and numbers on the phone.

Fabricio made associations between numbers and sales activities he was engaged with outside of school. He explained the products he sold had a "barcode, money." Pedro acknowledged numbers on car license plates, home numbers, and money. Junior and Cesar could not explain the use of numbers in their daily life, while Tiago, Hélio, and Maria chose not to speak.

Although students acknowledged the use of numbers in different everyday situations, not everyone had an understanding of the use of the numeric symbol as the representation of quantities.

The limited knowledge students had of numbers, that is, only as a symbolic representation dissociated from a quantitative value, could have been a result of a teaching and learning experience developed by means of repetitive activities only favoring the tracing of numerals without establishing a relationship between number and numeral, and the meaning of this relationship (SHIMAZAKI, 2006; VIGOTSKI, 2001). It could also have been a result of 
methodologies that did not go beyond excessive use of concrete material, thereby consisting of a barrier to abstraction of concepts (VIGOTSKI, 1997; GALPERIN, 2009a; GEERT, 1987). It can also be considered, in the case of this study, that the students' understanding of numbers have resulted from students learning in different social interactions both inside and outside school, with the intent of fulfilling the need for mathematical knowledge in their daily life. Regarding the money, all students understood its social function and also the relationship between the money and its value connected with the knowledge they had about numbers.

With regard to the action of counting, each student understood it differently, that is, regarding their everyday actions. When asked about what "to count" meant, the answer was: "doing the math", "counting to 31", "ordering the right goods", "not being mistaken" and two subjects answered that they did not know the usefulness of the number.

Despite the definitions given about the action of counting, it was found that many of them did not compute objects correctly; they did not count all objects only once by means of one-to-one correspondence, and did not quantify them by the end of counting. A similar result was found by Shimazaki and Pacheco (2012). They identified that students studying in a special class were unable to quantify and establish one-to-one correspondence between objects. Tiago, Maria, and Hélio were able to understand small amounts, ranging from three to four units. They assessed larger amounts by means of number sense, that is, one's ability to distinguish and compare quantities without resorting to counting (LOPES; ROOS; BATHELT, 2014). Tiago and Maria could not read nor write digits and counted to ten in the wrong order without quantifying elements after counting. Cesar, José, Fabricio, and Pedro had a more advanced understanding. They counted a larger number of objects appropriately, with such an amount varying from 20 to 50 . Nevertheless, they did not grasp the principles of the decimal number system. Junior counted even larger amounts and made simple mental calculation to assess different groups of objects. When asked what was the use of counting, the answer was:

Tiago: Gas bill, on the calculator. Paying for water, electricity, telephone, market.

José: Paying bills.

Cesar: To know, memory.

Hélio: I count when I go to the market.

Fabricio: I do division.

Researcher: Why do you do it?

Fabricio: Division, adding, subtracting, the one with the key. I do not know what it is for.

(Dialogue between researcher and student, 2015).

In regard to operations, Junior carried out addition and subtraction, while Fabricio carried out basic addition and subtraction with regrouping. Both of them, however, could not carry out operations properly when aiming at problem-solving. Fabricio always resorted to 
addition to solve any problem. When comparing his age to his colleague's to find out who was the oldest, he added both ages. When asked about the reason why he had done so, he answered: "I just did it." His answer exposed the importance of performing any calculation, whether he would solve the problem or not. According to Talizina's (2009) theory on concept appropriation, the student had not learned the logic structure of concept definition, but had only memorized different procedures that allowed him to perform the operation. It is possible that his teachers taught him how to perform operations in a mechanical and repetitive manner, out of the problem-solving context (HIEBERT; WEARNE, 2006; KAHAN; WYERG, 2006; BRASIL, 1997). This represents one of the problems regarding Mathematics teaching. Similarly, Junior was asked to compare two students in age. He claimed he was unable to do so, despite knowing how to perform operations. The other students could not perform operations with quantities.

Fabricio, Pedro, and Junior understood measurement tools, such as a metal ruler, meter stick, and scale. They established a relationship between quantity and the unit of measurement, possibly as a result of using some of those tools in activities related to bread making, as well as other everyday situations outside of school. This finding came about when students wondered what it was like to measure:

Fabricio: Measuring like this, the table, the wall.

Pedro: Measuring with the measuring tape, the table, the tank, measuring flour in baking.

Researcher: Is it measuring? (Related to flour)

Pedro: No, measuring is only with the measuring tape.

Junior: To see the height, measuring everything, measuring the mass on the scale, milk in the liter and eggs per box.

Researcher: How many eggs are in the box?

Junior: 12

(Dialogue between researcher and student, 2015)

The words "height", "meter", "measure", "measuring tape", "scale", "liter", showed the knowledge that these students had about the use of numbers as an instrument for comparing different quantities.

The fact that most students could recognize a few numerals, had some knowledge of those symbols being related to numbers, could quantify small amounts, and presented primary understanding about the social function that this concept had in their lives, did not mean they had consolidated the concept (TALIZINA, 2009). The actions of counting, that is, performing operations, were not defined; however, they were able to make connections between the concepts and everyday actions. In other words, they did so at the level of spontaneous concepts, rather than scientific concepts (VIGOTSKI, 2001). 
According to Salmina's (2001) lessons, similarly to any other concept, mathematical concepts cannot be internalized without one's appropriation of a system of primary knowledge and logic activities. Thus, there was a need to fill this gap before introducing soroban as a calculation tool. Knowledge developed by students in their daily life, especially in activities related to bread making, served as the basis for teaching mathematical concepts.

\subsection{Approach of the number concept}

Thus, the following tasks were proposed: classifying numbers, series, ordering, counting, and comparing objects by means of different strategies. For this, packages of different products were used, such as hygiene and cleaning products, food, and medicines. Verbal language was used with the intent of expressing the outcomes of actions. To Talizina (2009), the aforementioned actions aid logical thinking formation. The latter is necessary for one's appropriation of the number concept, as well as for comprehending the logic of the decimal number system.

One of the activities developed was package sorting. For that, two hexahedrons were used, one with quantity and the other with the type of material that the packages were made of. The students launched simultaneously and took the amount rolled by the dice of packages of a given material. Counting actions and comparison of quantities were explored. Other concepts such as: "everything”, "nothing”, "little", "half", "almost nothing”, "much" were used. One of the most difficult words was "half". As an example, Tiago was asked to separate half of the paper packages. It had previously been discussed that in order to find the half, it was enough to divide the objects into two groups with an equal amount. Tiago formed two groups, one with six objects, and the other with four, counting them with the help of the researcher:

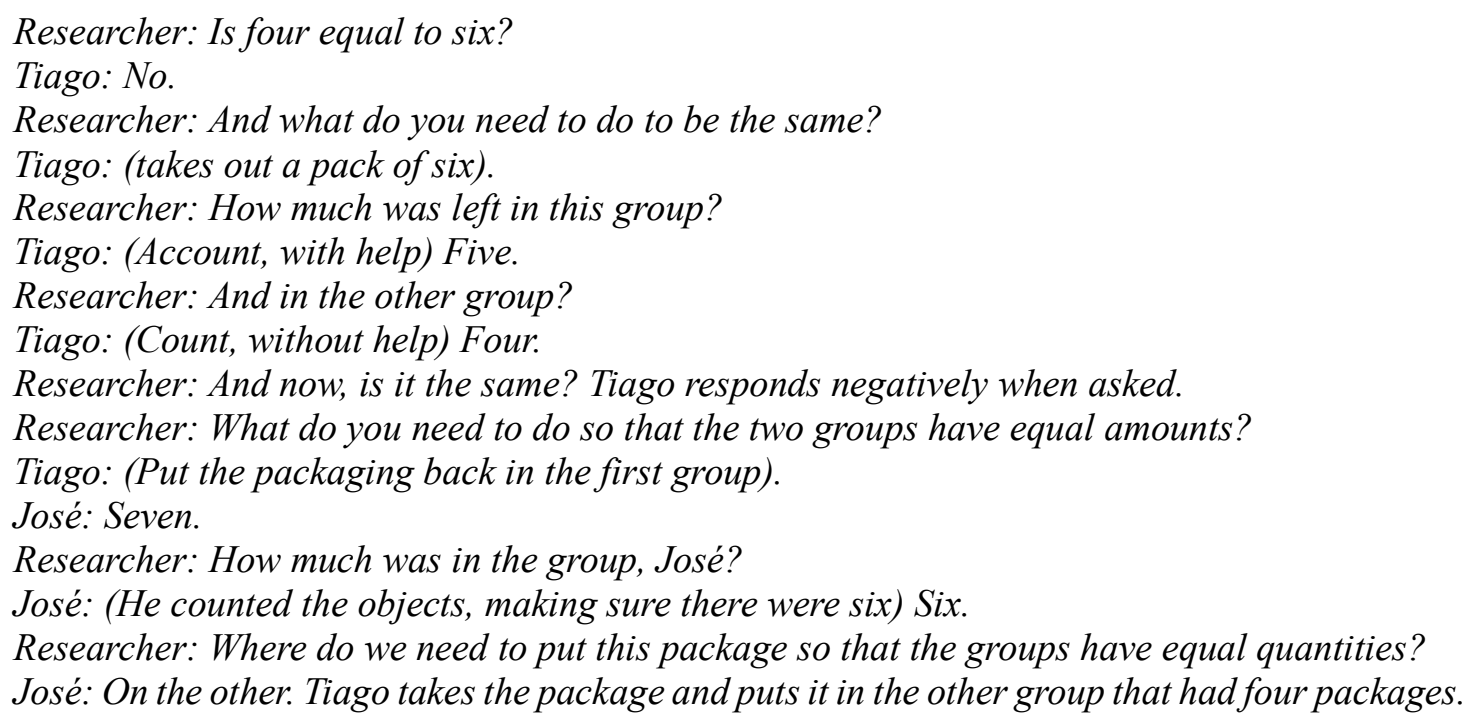


Researcher: And now, is it the same? Both answered yes

(Dialogue between researcher and student, 2015).

Tiago, despite having difficulties in counting, managed to compare the two quantities. José, when stating that the groups had equal amounts, showed doubt about the concept. It was necessary to carry out a two-way correspondence between the elements of the two groups to confirm equality between the groups. Due to the need that he always had of counting the elements of a set to quantify them, it was understood that he was in the process of appropriating the number concept, not yet abstracting the quantities.

Another activity developed with the packages was the sorting of objects using hula hoops, which represented the Venn diagram, used in mathematical language to represent, and perform operations between sets (SOUZA, 2019). In one of the hula hoops there were metal packages and, in the other, plastic packages. When the hula hoops were intersected, metal and plastic packages should be placed at the intersection. The students were able to identify common characteristics between the packages, not the differences. For example, they could not see a plastic cover in a metal package. The researcher's intervention was necessary, requesting their observation explaining the types of materials present in each package. For Vigotski (2001), the first step towards the abstraction of a concept happens when the student is able to group a maximum possible number of objects using two or more attributes as the basis, as in the given example of package classification through the Venn diagram. Figure 4 shows this activity:

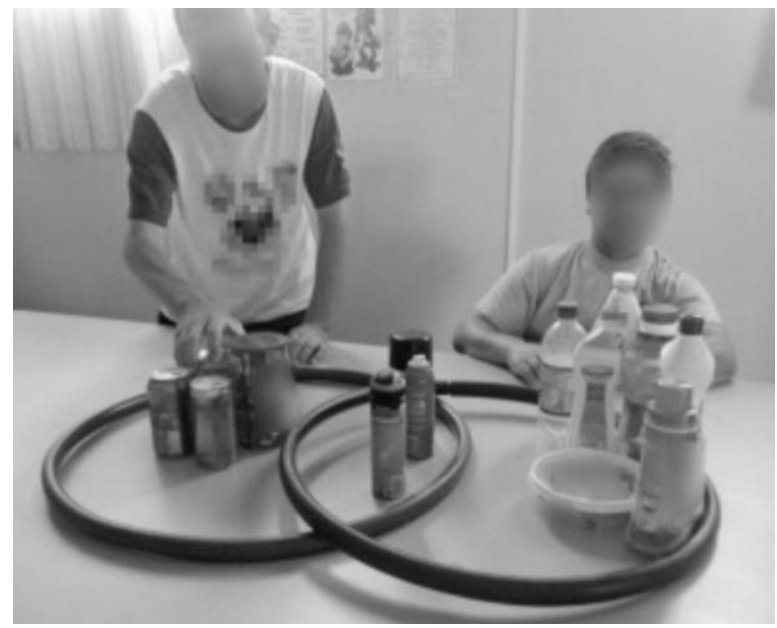

Figure 4 - Classification using the Venn diagram. Source: Researchers' private collection.

\subsection{Teaching the use of soroban to perform mathematical operations}

Following instructions provided by national guidelines for teaching operations, in which problem-solving is the starting point for mathematical activity (BRASIL, 1997), we introduced 
soroban as the tool used to record the amounts of objects and to allow comparisons between amounts, particularly with a view to solving problems related to the students' actions.

The first-time students were in contact with the tool, Maria, Tiago, and Hélio tended to place a higher number of beads near the reckoning bar than necessary. This was possibly due to the fact that they did not properly count amounts greater than three or four objects. Regarding the other students, difficulties arose whenever they needed to record numbers higher than five, since they were able to perform one-to-one correspondence with numbers up to four.

In performing the operation $3+1$ on the soroban, the students added one unit to the other three which were already recorded on the inferior part of the first rod, henceforth constructing it as if it were a mechanical operation. The operation $9-2$ was carried out in a similar way, subtracting two units from the inferior first rod, resulting in 7. Other operations were proposed with the objective of promoting reasoning regarding to the operations students were performing on the soroban. These additional operations had small numbers, but demanded thought to record the response, among them $4+1 ; 5-2 ; 3+2 ; 5-4 ; 5+3 ; 9-2$. Taking for example, $4+1$, one must perform a mental calculation in order to obtain the final total of 5 and proceed in recording this result on the soroban.

It is noteworthy that, in addition to the students performing addition and subtraction operations, the activities promoted reflections about inverse operations, that is, the ability to return to the starting point through "denial", "inversion", or "reciprocity". An example of this is the speech of Pedro, who, when carrying out operation 4-1, pointed out: "iffour minus three is one, four minus one can only be three".

Another operation that brought along some challenges in finding the answer was $5-1$. To solve this operation, one should go back to the complementary numbers of 5 , in this case, 4 and 1 . For situations like this, there was a need to address the complementary numbers of the number $5(4+1 ; 3+2 ; 2+3$ and $1+4)$ and in other situations, number $10(9+1 ; 8+2 ; 7+3$; $6+4 ; 5+5 ; 4+6 ; 3+7 ; 2+8 ; 1+9)$. For that, we used the Numerical Rules, through which the students assembled the pairs that make up the number 5, and made use of this construction as a material resource, consulted whenever they needed such numerical facts.

In the case of the 5-1 operation, it was necessary to perform the reverse operation, eliminating the number five on the upper part and recording the number four on the lower part. José wanted to take away units from other rods, and when he received the tip that he was working with units, recording them only on the first rod he responded, "you don't say where to take it away from". This reveals the student's dependence on the teacher in carrying out the activity, possibly originating from teaching situations in which he was not given incentive to 
think and act independently. Potentially, the fear of making a mistake and not passing could also be a cause.

As the participants began to construct the number concepts, for example, their understanding of larger amounts, the use of counting as a means to quantitatively evaluate a numeric set, the comprehension of altering numbers by means of adding and subtracting quantities, and grouping by tens, they began to use the second rod of the soroban to work with quantities larger than ten. They also found it challenging to grasp that the second rod was intended to record groupings of ten units and it was common for them to consider a one-unit value for the upper bead on the first rod. When this happened, the researcher made use of the golden bead material to explain the need to change the axis, as the groupings happened in increments of ten. As an example, Fabricio's record of number 20 on the soroban is represented below in Figure 5:

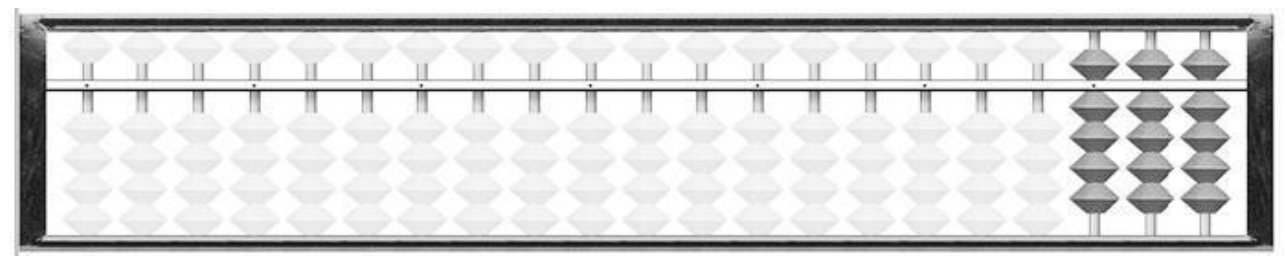

Figure 5 - Fabricio's record of number 20. Source: Researchers' private collection.

The student was asked whether the number recorded on soroban was the number 20 . He answered: "No. It's 19." Fabricio was then required to explain why the record represented the number 19. On the first rod, he counted "five, six, seven, eight, nine" taking into account that the upper bead was worth five, while the lower bead was worth four. On the other rods, he assigned a one-unit value to all beads, thus totaling 19 .

Up to that moment, he had recorded values not greater than 30 . For this reason, there had not been the need to use the upper bead on the second rod that represents five sets of tens. He could have considered that only the first rod had an upper bead worth five. There was a recurrent need to remind them that upper beads had different values from lower beads. This was potentially connected to the fact that they had not yet abstracted different values assigned not only to lower and upper beads, but also to each rod. Nevertheless, Fabricio's action exposed he made advances towards counting, which had not previously happened. He counted from five onwards, that is, without the need for one-to-one correspondence in counting.

In order to promote understanding of numbers higher than five, composition was used by means of adding complementary numbers $(6=5+1 ; 7=5+2 ; 8=5+3$ e $9=5+4)$ (KAMII; DECLARK, 1997). Manipulative materials, for instance, numbered rulers, golden 
beads, bills, as well as clotheslines with clothespins, combined with card games such as steal the pile, Battle and war, and domino addition (FERNANDES et al., 2006) were used. Thereafter, students recorded addition and subtraction resulting from compositions on the soroban.

Therefore, the number concept was developed as a result of adding complementary numbers previously appropriated by students; that is, without exclusively relying on the students' memory, but on action over objects to perform addition of number pairs not greater than ten (FERNANDES, 2006). The formation of addition results on the mental plane not only allows those other numbers to be appropriated, but also speeds up calculation procedures (DONLAN; WU, 2017; SOUZA FILHO, 2013). Fabricio's explanation as to how he recorded the number 20, as previously described is the real example. He counted from five onwards and not from one onwards since he had already internalized the value of five assigned to the first rod upper bead.

\subsection{The use of soroban to solve problems}

One of the scenarios used for teaching the soroban was carried out on the basis of work developed by students in bread making. This promoted a connection between academic activities and activities they developed in this sector. The proposal made to students was to calculate the costs their school incurred to produce sliced bread, a product they had chosen.

One of the first tasks was to record a bread recipe. This was then followed by a survey on the price of ingredients. Different supermarket fliers were used for price comparison. The lowest price was then chosen. Fabricio had sales skills, thus, he suggested round numbers were used to streamline calculations.

An ad for margarine on sale in one of the fliers called students' attention: "Three for the price of two" (two containers of margarine for R $\$ 2.98$ each, and the third one for free). Another supermarket sold margarine for $\mathrm{R} \$ 2.68$. When asked about which margarine they should buy, Fabricio pointed at the sales flier and answered: "That one is cheaper, the other one is more expensive".

We found out he did not compare prices, but noticed the sales advertisement. Subsequently, Fabricio made the price a round three, and despite being sure of his answer, he was unable to come up with a strategy to find out the price of each margarine container. Junior also thought buying margarine on sale was the answer; however, he could not perform an operation to solve the problem. This confirms what had already been previously observed. He 
was able to perform a few addition and subtraction operations, but was not aware of which operation to use when dealing with a problem.

Fabricio, Pedro, and Junior's difficulties related to problem-solving were not connected to arithmetical concepts, but to understanding the situation highlighted through the problem. This does not mean they were unable to interpret the problem correctly, but that they needed mediation to select the actions necessary to solve the problem (TALIZINA, 2009).

According to Vigotski (2001), the greatest difficulty is applying a concept developed and formulated at an abstract level to new situations which, in turn, have to be dealt with in similar abstract terms. The theorist claims transition from abstract to concrete is as difficult as the transition from concrete to abstract.

As the students did not point out a strategy to discover the price of each margarine container on sale, language ended up being the mediating tool used so that the students could solve the problem. This allowed them to grasp the concept studied, in addition to providing them with autonomy (SHIMAZAKI; PACHECO, 2012).

Students were asked the total of the three containers cost together. Pedro answered $\mathrm{R} \$ 6.00$. To find out the price of each container, they were advised to use bills, and Pedro chose three 2 Reais bills. They were told they needed to find out how many bills were necessary for each container. Thus, they performed division, distributing a 2 Reais bill for each object. Therefore, they concluded that each container cost $\mathrm{R} \$ 2.00$. As a result, they confirmed Fabricio's answer. Students were informed that Pedro had divided the total price into three parts, thus finding the price of each item. Division was carried out by students using the soroban to perform subtraction.

The yeast used in baking also generated discussion because the whole piece weighs $500 \mathrm{~g}$ and cost six reais and the recipe required $300 \mathrm{~g}$. It was questioned how to calculate the cost of $300 \mathrm{~g}$. At first the students did not find any strategy for the resolution. Junior replied that each $100 \mathrm{~g}$ would cost two reais. It was asked how much $300 \mathrm{~g}$ would cost, he replied: "nineteen reais" and was unable to explain the operation that he carried out to reach that value. It was explained that one part could not cost more than the entire product. The following dialog shows the interaction between the researcher and the student:

Researcher: If five hundred grams cost five reais, how much would each hundred grams cost? Junior: One real.

Researcher: And three hundred grams?

Junior: Three reais.

Researcher: And how much is the value?

Junior: One more real.

Researcher: And a real divided into five parts, how much is it? 
Junior: Twenty cents.

Researcher: How much does $100 \mathrm{~g}$ cost then?

Junior: One real and twenty cents.

Researcher: And 300g?

Junior: Three reais and sixty cents.

(Dialogue between researcher and student, 2015)

The researcher uses the stage of verbal language in the teaching process, offering them possibilities of reasoning about a problem. When calculating the final price, Junior made use of a mental sum operation. Pedro and Fabricio received assistance through the use of pedagogical notes and coins and exchanged one real for ten coins of ten cents so that they could divide the cents into five parts. These operations were performed on the soroban through addition and subtraction.

Junior directly answered questions related to dividing ingredients into parts, for instance, he was asked to find out the price of three eggs based on the price of a dozen. It seemed that problems of this nature were rather common in his daily life, which led him to resort to practical reasoning to solve them. The aforementioned situations were not only about performing one operation or another, but also thinking about the correct operation necessary to solve the problem. On this matter, Carraher, Carraher and Schiliemann (1997, p. 35) were grounded in another theoretical perspective on learning and development, and claimed that " $[$... $]$ logical analysis required for problem-solving provides ease for performing operations, as the former inserts the latter into a system of well-understood meanings, instead of allowing them to consist of discrete skills performed in a series of steps that lead to resolution."

While the activity was carried out, several materials were used to represent the problem, with the specific aim of promoting a better understanding of necessary actions. According to Talizina (2009), the action of building models is widely used for problem solving. The student must know how to make a transition from the verbal model to the thematic model. Problemsolving is achieved as a transition from one model to another; from the textual model, as well as supplementary models such as graphs, tables, mathematical model schemes, the framework upon which problem solving is built.

To Talizina (2009), for students to learn how to solve an operation, the teacher tells them all necessary actions which should be carried out in a specific order. Nevertheless, who determines the actions necessary to solve a problem is the student. This applies not only to the teaching of standard algorithm, but also to the teaching of soroban. To this end, the student needs to be familiar with the principles of arithmetic, in addition to understanding the essence of problem-related basic elements and their inter-relations. As for intellectually disabled 
students, they often do not have enough autonomy to determine the necessary actions. Therefore, teacher's mediation is of paramount importance as it guides them through action.

Talizina (2009) also advocates that whenever proposing a problem to their students, the teacher expects them to come up with a solution. However, this teacher should provide them with conditions that allow the students to argue and explain the procedures used to solve the problem, all of which by means of reflection. This is achieved when teaching has been planned with the intent of including but not being limited to a material-based step, while moving forward towards linguistic and reasoning steps (GALPERIN, 2009a; VIGOTSKI, 1997).

By the end of the pedagogical intervention, there were conceptual changes undergone by the students, particularly regarding the addressed content. Students Hélio and Cesar did not show more significant progress due to frequently missing sessions during pedagogical intervention.

Regarding the number concept, Tiago, Hélio, and Maria, who demonstrated understanding of small amounts at the beginning of investigation, went on to quantify larger amounts of objects without resorting to one-to-one correspondence to compute them. This opened up ZPD for further consolidation of other number concepts. When using the soroban, they operated with amounts up to five. Fabricio, José, and Pedro started understanding the principles of the decimal number system, such as grouping every ten units and place values, and also performing addition and subtraction operations with smaller numbers on the soroban. For numbers higher than 20, students still needed support provided by other materials, such as golden beads. They went on to think about which operation they should use for problemsolving, all under the researcher's mediation. In counting, Pedro began to count every two, three, four, and six objects. This was something he was unable to do before the intervention. Junior was able to understand the principles of the decimal number system based on grouping every ten units, to read and record 3-digit numbers on the soroban, as well as how to perform addition and subtraction operations. He had some difficulty with operations requiring regrouping or changes; however, he was able to perform them independently.

Particularly regarding teaching on how to use the soroban, the greatest difficulties were related to the fact that students had not yet consolidated the number concept or the principles of the decimal number system (FERNANDES, 2006). This led to doubt when they tried to correctly record numbers on the soroban, except for Junior.

By the end of research, three students had understood the concept of numbers four and five; three students had appropriated both the concept of higher numbers and the decimal number system structure concept, including place value and counting by grouping of tens. One 
student, who had not performed operations properly for problem-solving, went on to do so. Particularly on the use of the soroban, two students could not learn how to use it due to missing a high number of teaching sessions. Two other students learned how to read and record numbers up to five, and also learned how to perform addition and subtraction with those numbers. Three students learned how to record and perform operations (addition and subtraction) with amounts up to 20; and one student learned how to perform operations of addition and subtraction with 3-digit numbers (hundreds), thus opening up ZPD for further consolidation of other operations, such as multiplication and division.

\section{Final considerations}

With this study, we can defend that the cognitive limitations of intellectually disabled people are not barriers for learning not only the concept of numbers, but also how to perform operations with the aid of the soroban. The latter proposed the development of an action plan to be implemented by means of pedagogical intervention with intellectually disabled students attending the EJA program.

Teaching the soroban to students allowed them to have access to mathematical knowledge, in addition to understanding concepts that had remained in the students' ZPD.

During this process, the students were actively engaged by means of a set of actions guided by mediation. As a result, students went on to assign a different meaning to the concept of numbers based on different situations provided by social practice.

Although students often felt they lacked confidence to use verbal language to present their ideas to the group or even to describe their actions over objects, we noticed the importance of that step in the teaching process. Students' oral expression allowed for comprehension of the strategies they used to solve specific situations and provided support to our pedagogical practice. This was made possible via mediation, where students were given the opportunity to use verbal language. The opportunity students had to express their thoughts helped them overcome a feeling of inferiority arising from the social treatment to which they had been subjected over time.

A few limitations were identified in the present study, namely: students' difficulty in communicating, which restricted more conclusive claims during analyses of results; students' understanding of number concepts, which restricted further advances in learning concepts related to numbers and operations content; the time assigned to develop the intervention, that is, other results could have been found within a longer time period; the study being developed 
in an elementary school focusing on SE, not in a general education program in which students would be in situation of inclusion; and the use of Golden Soroban only by intellectually disabled students.

In view of such limitations, new perspectives are opened up for this study to be continued, as well as for the development of new studies employing soroban as their theme. Among those, we highlight the importance of developing studies aimed at investigating the effects of soroban on teaching Mathematics for a longer period of time and to classes other than EJA. Likewise, we also encourage developing studies with intellectually disabled students attending a general education program, which could contribute to teaching the subject in situations of inclusion.

\section{Acknowledgments}

This research was developed with the support of the Brazilian Council for Scientific and Technological Development, Brazil.

\section{References}

BRASIL. Ministério da Educação. Parâmetros Curriculares Nacionais: Matemática. Brasília: MEC, Secretaria de Educação Fundamental, 1997.

BRASIL. Senado Federal. Constituição da República Federativa do Brasil. Brasília: texto constitucional promulgado em 5 de outubro de 1988, com as alterações determinadas pelas Emendas Constitucionais de Revisão nos 1 a 6/94, pelas Emendas Constitucionais nos 1/92 a 91/2016 e pelo Decreto Legislativo no 186/2008. Brasília: Senado Federal, 2016.

BRASIL. Senado Federal. Lei de Diretrizes e Bases da Educação Nacional. Brasília: Senado Federal, 2017.

BRAUN, P.; NUNES, L. R. O. de P. A formação de conceitos em alunos com deficiência intelectual: o caso de Ian. Revista Brasileira de Educação Especial, Marília, v. 21, n. 1, p. 75-92, 2015.

BRITO, J. de; CAMPOS, J. A. de P. P.; ROMANATTO, M. C. Ensino de matemática a alunos com deficiência intelectual na educação de jovens e adultos. Revista Brasileira de Educação Especial, Marília, v. 20, n. 4, p. 525-540, 2014.

CARRAHER, T.; CARRAHER, D. W.; SCHLIEMANN, A. D. Na vida dez, na escola, zero: os contextos culturais. In: CARRAHER, T.; CARRAHER, D. W.; SCHLIEMANN, A. D. (Org.) Na vida dez, na escola, zero. São Paulo: Editora Cortez, 1997. p. 23-44.

DONLAN, C.; WU, C. Procedural complexity underlies the efficiency advantage in abacus-based arithmetic development. Cognitive Development, Langford Lane, n. 43, p. 14-24, 2017.

FÁVERO, M. H. A pesquisa de intervenção na psicologia da educação matemática: aspectos conceituais e metodológicos. Educar em Revista, Curitiba, n. Especial 1, p. 47-62, 2011. 
FÁVERO, M. H.; OLIVEIRA, D. de. A construção da lógica do sistema numérico por uma criança com síndrome de down. Educar em Revista, Curitiba, n. 23, p. 67-75, 2004.

FERNANDES, C. T; BORGES, E. V. A.; SOUZA, M. S. B.; MOTA, M. G. B.; RESENDE, T. R. M.; LIMA, W. A construção do conceito do número e o pré-soroban. Brasília: Ministério da Educação, Secretaria de Educação Especial, 2006.

FERNANDES, C. T. De lá para cá...daqui para lá: as operações matemáticas nas velhas tábuas de contar. Revista Benjamin Constant, Rio de Janeiro, n. 35, p. 3-6, 2006.

GOMES, A. L.L.V.; POULIN, J. R.; FIGUEIREDO, R. V. de. A educação especial na perspectiva da inclusão escolar: $o$ atendimento educacional especializado para alunos com deficiência intelectual. Brasília: MEC/SEESP, 2010.

FIORENTINI, D. Alguns modos de ver e conceber o ensino da matemática no Brasil. Revista Zetetiké, Campinas, ano 3, n. 4, 1995.

FIORENTINI, D.; LORENZATO, S. Investigação em educação matemática: pressupostos teóricos e metodológicos. 3. ed. Campinas: Autores Associados, 2012.

FLICK, U. Introdução à pesquisa qualitativa. 3. ed. Porto Alegre: Artmed, 2009.

FREEMAN, N. Does the Japanese abacus improve underachieving children's performance in mathematics? Proceedings of the British Society for Research into Learning Mathematics, Leicester, v. 34, n. 3, p. 13-18, 2014.

GALPERIN, P. Y. La formación de las imágenes sensoriales y los conceptos. In: ROJAS, L. Q.; SOLOVIEVA, Y. (Org.). Las funciones psicológicas en el desarrollo del niño. México: Trillas, 2009a. p. 64-75.

GALPERIN, P. Y. Tipos de orientación y tipos de formación de las acciones y los conceptos. In: ROJAS, L. Q.; SOLOVIEVA, Y. (Org.). Las funciones psicológicas en el desarrollo del niño. México: Trillas, 2009b. p. 76-79.

GEERT, P. V. The structure of Galperin's model of the formation of mental acts. Human Development, Basel, v. 30, n. 6, p. 355-381, 1987.

HIEBERT, J.; WEARNE, D. Developing understanding through problem solving. In: SCHOEN, H. L. (Ed.). Teaching mathematics through problem solving: grades 6-12. Iowa: National Council of Teachers of Mathematics, 2006.

KAHAN, J. A.; WYBERG, T. R. Mathematics as sense making. In: SCHOEN, H. L. (Ed.) Teaching mathematics through problem solving: grades 6-12. Iowa: National Council of Teachers of Mathematics, 2006.

KAMII, C.; DECLARK, G. Reinventando a aritmética: implicações da teoria de Piaget. Campinas: Papirus, 1997.

LOPES, A. R. L. V.; ROOS, L. T. W.; BATHELT, R. E. Sobre a construção do número. In: BRASIL. Ministério da Educação. Pacto nacional pela alfabetização na idade certa: quantificação, registros e agrupamentos. Brasília: MEC/SEB, 2014. p. 6-9.

MAHPOP, H.; SIVASUBRAMANIAM, P. Addition of whole numbers with regrouping using the "soroban". Procedia Social and Behavioral Sciences, Langford Lane, n. 8, p. 50-56, 2010. 
MOREIRA, H.; CALEFFE, L. G. Metodologia da pesquisa para o professor pesquisador. 2. ed. Rio de Janeiro: Lamparina, 2008.

PARANÁ. Secretaria de Estado da Educação. Departamento de Educação Especial e Inclusão educacional. Organização administrativa e pedagógica das escolas de educação básica, na modalidade educação especial, para oferta de educação infantil, ensino fundamental anos iniciais, fase I da educação de jovens e adultos e educação profissional. Área da Deficiência Intelectual, Múltiplas Deficiências e Transtornos Globais do Desenvolvimento. Curitiba:

SEED/DEEIN, 2014.

SALMINA, N. G. La enseñanza de las matemáticas en la escuela primaria. In: TALIZINA, N. (Org.) La formación de las habilidades del pensamiento matemático. México: Universidad Autónoma de San Luis Polosí, 2001. p. 40-86.

SHEN, H. Teaching mental abacus calculation to students with mental retardation. The Journal of the International Association of Special Education, Fresno, v. 7, n. 1, p. 56-66, 2006.

SHIMAZAKI, E. M.; PACHECO, E. R. Deficiência e inclusão escolar. Maringá: Eduem, 2012.

SHIMAZAKI, E. M. Letramento em jovens e adultos com deficiência mental. Tese (Doutorado em Educação) - Universidade de São Paulo, São Paulo, 2006.

SCHALOCK, R. L., BORTHWICK-DUFFY, V. J. B, BUBTINX, D. L. C., BRADLEY, V. J., ELLIS, M., GOMEZ, S. C.; YEAGER, M. H. Intellectual Disability: definition, classification and systems of support. Washington: AAIDD, 2010.

SIANG, K. T. The modality factor in two approaches of abacus-based calculation and its effects on mental arithmetic and school mathematics achievements. 2007. 383f. Thesis (Doctor of Philosophy) - University Sains, Malaysia, 2007.

SOUZA FILHO, F. F. de. O soroban e sua aritmética. 2013. 213f. Dissertação (Mestrado Profissional em Matemática em Rede Nacional) - Universidade Federal do Piauí, Teresina, 2013.

SOUZA, M. G. de. Conjuntos e funções: conceitos, propriedades e demonstrações visando à formação continuada do professor de matemática da educação básica. Ponta Grossa: Editora Atena, 2019.

TALIZINA, N. La teoría de la actividad aplicada a la enseñanza. Puebla, 2009.

TANAKA, S. SEKI, K, HANAKAWA, T., HARADA, M., SUGAWARA, S. K., SADATO, N., WATANABE, K.; HONDA, M. Abacus in the brain: a longitudinal functional MRI study of a skilled abacus user with a right hemispheric lesion. Frontiers in Psychology, v. 3, p. 1-13, 2012.

VIGOTSKI, L. S. A formação social da mente. 6. ed. São Paulo: Martins Fontes, 2007.

VIGOTSKI, L. S. Fundamentos de defectologia. Obras Escogidas5. Madrid: Visor, 1997.

VIGOTSKI, L. S. Pensamiento y linguaje. Obras Escogidas2. Madrid: Visor, 2001. 
